\title{
Action of Essential Oils on Sprouting of Non-Dormant Potato Tubers
}

\author{
Fernando Luiz Finger ${ }^{1 *}$, Mirelle Mayana de Sousa Santos ${ }^{1}$, Fernanda Ferreira Araujo ${ }^{1}$, \\ Paula Cristina Carvalho Lima ${ }^{1}$, Lucas Cavalcante da Costa ${ }^{1}$, Christiane de Fatima Martins \\ França $^{2}$, Matheus da Costa Queiroz ${ }^{1}$ \\ ${ }^{1}$ Universidade Federal de Vicosa, Planta Biology Vicosa, MG, Brazil; ${ }^{2}$ Universidade Federal do Oeste da Bahia, \\ Campus Multidiciplinar de Barra,Barra, Bahia, Brazil
}

\begin{abstract}
The breakdown of dormancy and early sprouting is one of the main causes of losses of stored potatoes. Sprouting control becomes important especially when tubers are submitted to long-term storage for further processing by the potato industry. The objective of this work is to evaluate the effect of organic sprout inhibitors, eugenol and menthol essential oils, on the suppression of growth on non-dormant 'Asterix' tubers stored at $8{ }^{\circ} \mathrm{C}$. Administration of eugenol and menthol essential oils reduced the number and the length of sprouts during cold storage up to fifty days. Nevertheless, the essential oils stimulated the break of bud apical dominance, stimulating auxiliary buds growth. The effect of the oils was restricted to inducing necrosis of superficial sprout cells without any apparent effect on the skin periderm structure. Repeated applications of oils are necessary to prolong the inhibitory effects of the essential oils on sprouts growth.
\end{abstract}

Keywords: Solanum tuberosum, eugenol, menthol, buds, periderm.

*Author for correspondence: ffinger@ufv.br 


\section{INTRODUCTION}

Total production of potato in Brazil reaches 3.5 million tons per year, however only a small fraction is processed by the industry ${ }^{1}$. It is estimated that the urban Brazilian population will be approximately eight-fold bigger than the rural by the year 2020, increasing the demand for more convenient processed food products ${ }^{2}$. As consequence of urban population growth, since 2003, the consumption of frozen pre-fried French fries has increased from 77,000 to 314,000 tons in the year $2012^{3}$. The perspective of growth for frozen potato products in Brazil is estimated at $15 \%$ per year ${ }^{4}$.

Among the cultivars produced in the country for French fries, 'Asterix' responds for most of the frozen pre-fried potatoes, followed by 'Markies', 'Challenger' and 'Ludmilla'. The choice for 'Asterix' is based on excellent yields, and good qualities for French fries required for the Brazilian's consumers, in particular due to the yellow flesh color and flavor. Nevertheless, the tubers have relative short period of dormancy, which requires the use of sprout inhibitors for long-term storage. The end of dormancy results in increased respiratory rate, elevated loss of water, degradation of starch and consequent buildup of soluble sugars ${ }^{5}$.

Chlorpropham (CIPC) is the most effective sprout inhibitor used in bulk storage of fresh market and for processing potato. CIPC inhibits cell division, usually applied by fogging just after wound healing and before the potato pile settles. Because of remaining residue left in the tubers, the use of CIPC is raising questions concerning toxicology and possible effects on the environment in both USA and by the European Union, lowering the admissible tolerance limits for CIPC ${ }^{6}$. In addition, CIPC is not registered as growth regulator for potato in Brazil, being prohibited for use or commercialization.

In the more recent years, several less harmful alternative chemicals have been tested to replace CIPC for the control of dormancy and the growth of sprouts in stored potatoes. Several options for controlling the sprouting have been commercialized, including essential oils, naphthalene derivates, unsaturated ketones, ethylene and stabilized hydrogen peroxide ${ }^{5}$.

Previous works have shown the efficacy of essential oils from some herbs and spices in reducing sprouting in potato tubers ${ }^{7,8,9}$. In addition, the plant-derived essential natural compounds, including mint, peppermint and clove essential oils leave no residue on the tubers, which allow these compounds to be applied in organic farming ${ }^{10}$. But, the efficiency of these alternative inhibitors depends on the cultivar, temperature of storage, progression of tuber dormancy, concentration, time and number of applications, and mode of the chemical action. The essential oils act by physically burning the bud meristematic tissue, which may require more than one application and they are efficient in reducing the sprout growth after the end of dormancy ${ }^{11,6}$. Nevertheless, little is known about the effects of the essential oils on the sugar accumulation and quality of the French fries.

The effectiveness of essential oils in suppressing the sprout growth of non-dormant commercial varieties of potatoes grown in Brazil is not determined yet. The objective of the present work was to evaluate the physiological, physicochemical and anatomical effects of eugenol and menthol in cold stored potato tubers of 'Asterix'. 


\section{MATERIAL AND METHODS}

Potato plants of 'Asterix' were grown from May to August in the micro region of Araxá $\left(19^{\circ} 35^{\prime} \mathrm{S}, 46^{\circ} 56^{\prime} \mathrm{W}, 1000 \mathrm{~m}\right.$ a.s.l.), were harvested after the death of the vines, and tubers between 150-200 g were cured for ten days at $14{ }^{\circ} \mathrm{C}$ and $90 \%$ relative humidity. Afterwards, the temperature was lowered at rate of $1{ }^{\circ} \mathrm{C}$ per day to $8{ }^{\circ} \mathrm{C}$ and relative humidity $90-95 \%$ and stored for three months. After the natural dormancy was broken, at early sprouting stage (sprouts with less $5 \mathrm{~mm}$ in length), tubers were treated with eugenol and menthol at 50\% solution in 95\% ethanol. A total of 35 tubers were placed in $65 \mathrm{~L}$ sealed containers containing a petri dish with $2 \mathrm{ml}$ of solution, with final concentration of $100 \mathrm{mg} / \mathrm{kg}$ of potato. The essential oils were vaporized, according to the method described by Vaughn and Spencer ${ }^{11}$ for a period of two hours with the help of a hot plate, returning to the cold storage afterwards. Control tubers were treated with vapor of ethanol for the same period.

Analysis of tuber sprouting was performed at day of treatment application and after 10, 20, 30, 40 and 50 days. Throughout the storage, tubers were weighed to estimate the accumulated fresh mass loss. The number and length of sprouts were counted, and the length of the sprout $(\mathrm{mm})$ was determined with the help of a caliper. The values for the incidence of sprouting were calculated considering the highest number of sprouts as $100 \%$.

Sprout samples from control, menthol and eugenol treated tubers were removed for anatomical analyzes, performed by light microscopy were fixed with FAA50 (50\% ethanol: $10 \%$ formaldehyde: $5 \%$ acetic acid: $35 \%$ water; v/v/v/v) for 48 hours and then maintained in $70 \%$ ethanol ${ }^{12}$ until analysis. The samples were reduced to $0.25 \times 0.25 \times$ $0.25 \mathrm{~mm}$, and then the tissue was dehydrated in ethanol (70,80, and 95\%) for 2 hours each, followed by imbibition in Epon resin with ethanol (1:1) for one week; afterwards in pure resin at $60{ }^{\circ} \mathrm{C}$, for 48 hours. After the solidification of the resin, cuts were made in ultrafine sections, using a Leica microtome, model Spencer. The sections were stained with toluidine blue, viewed with microscope Olympus AX70, and documented using an Axion Vision Rel 4.8 software.

The experimental design was performed in completely randomized in split-plot design, with the compounds of menthol and eugenol as plots and six sampling times as subplots. The experiment was composed of four replicates per treatment and an experimental unit consisting of twenty potato tubers. The data were analyzed by variance and regression analysis using the Statistical Analysis System 9.1 ${ }^{13}$. The choice of the regression models were based on the significance of the regression coefficients using the $5 \%$ probability level test in the coefficient of determination $\left(\mathrm{R}^{2}=\mathrm{SQReg} / \mathrm{SQtrat}\right)$ and biological behavior under the study.

\section{RESULTS AND DISCUSSION}

Regardless the treatment applied, fresh mass loss accumulated in a linear fashion over the 50-day period of storage (Figure 1). At constant rate of mass loss, by the end of the evaluation period, the estimated losses were $6.8,7.9$ and $6.6 \%$ for the control, eugenol and menthol treatments, respectively. The highest daily rate of loss was $0.16 \%$ for the tubers treated with eugenol. As observed in most of the horticultural products, the loss of fresh mass during storage accumulates in a linear manner. 


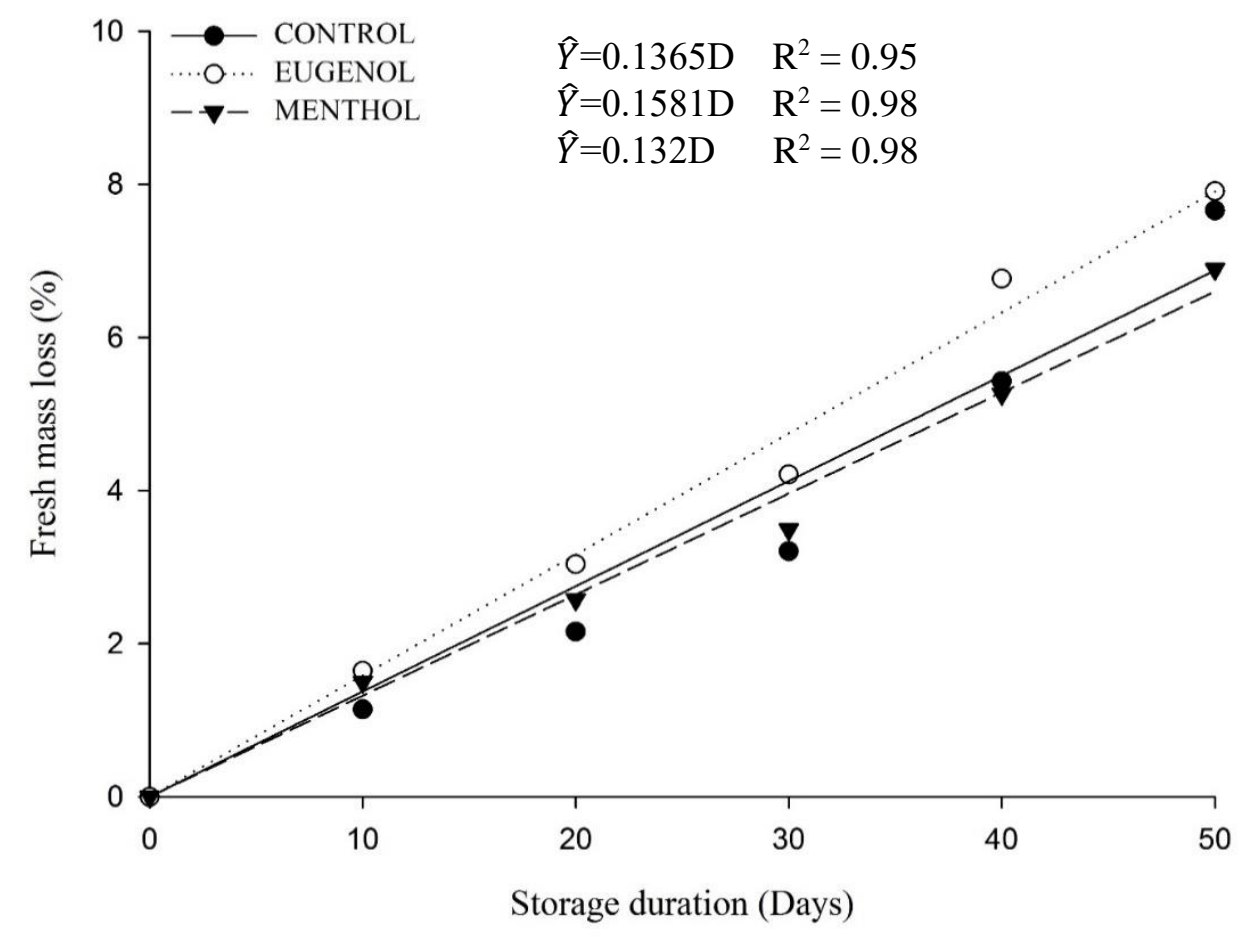

Figure 1. Fresh mass loss (\%) of 'Asterix' potato tubers as a function of storage duration (days) at $8{ }^{\circ} \mathrm{C}$.

Treatment with menthol resulted in the lowest percentage of sprouting compared to control and eugenol treated tubers throughout the storage (Figure 2). Compared to the day of oils treatment, in the following 10 days after treatment, the percentage of sprouting increased by 1.6, 1.5 and 1.4-fold for control, eugenol and menthol, respectively. Even with the appearance of lateral shoots in the oil treated tubers, at 40 days of storage, those tubers treated with eugenol and menthol presented lower sprouting percentages, with 88.8 and $67.4 \%$, respectively, compared to the $92.9 \%$ on control tubers (Figure 2 and 3). The increase in the number of shoots at the end of the experiment, after 50 days, evidenced the need for additional applications of eugenol or menthol during storage, in the attempt to keep the tubers commercially marketable (Figure 3). 


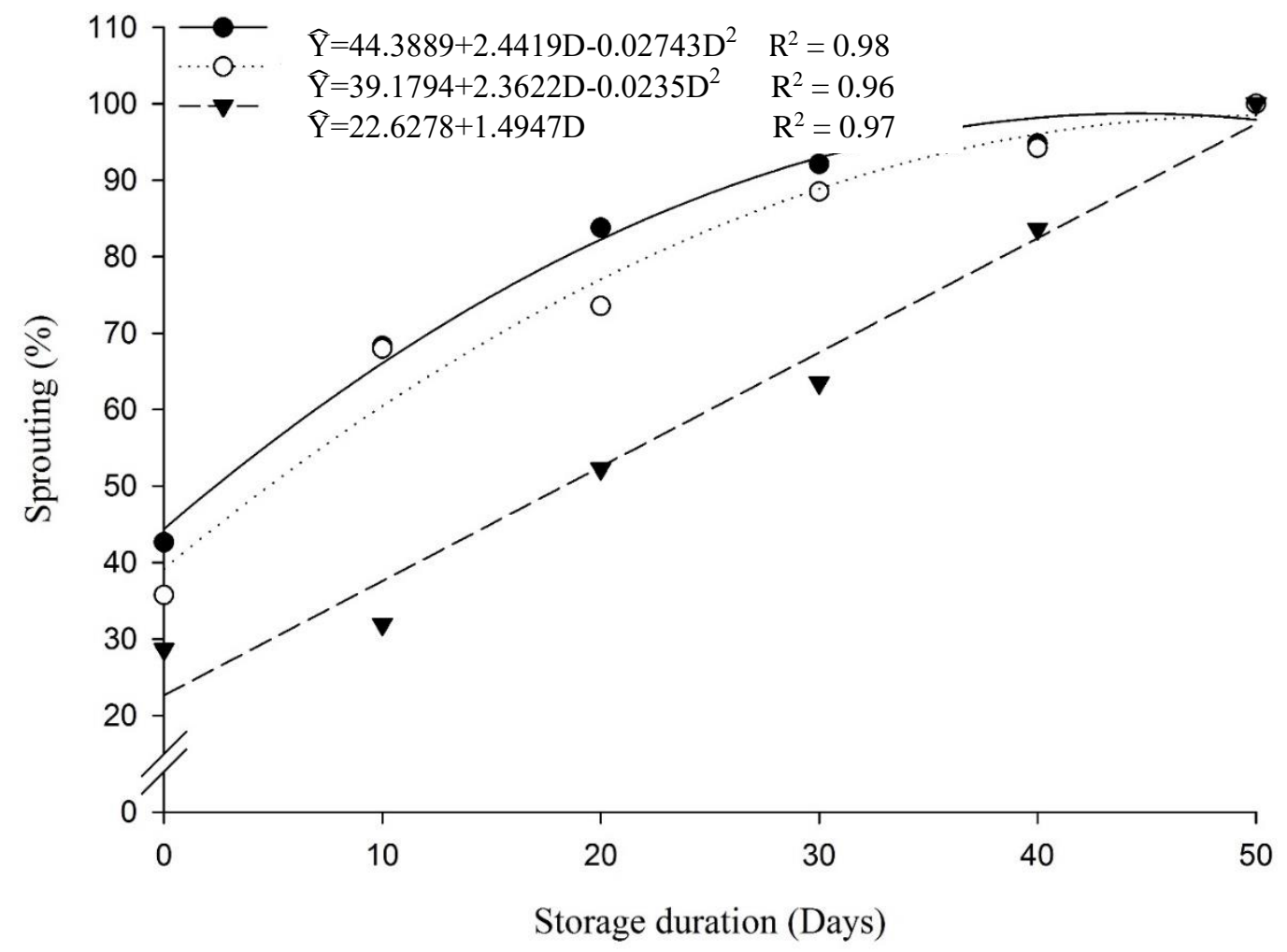

Figure 2. Total percentage of tuber sprouts of 'Asterix' stored at $8{ }^{\circ} \mathrm{C}$ treated with eugenol $(0)$, menthol $(\boldsymbol{\nabla})$ and control $(\bullet)$ tubers.

Up to the fifty-day of storage, visual analysis showed that menthol treated tubers presented the shortest sprouts, followed by the eugenol treated tubers and then control (Figure 3). Goméz-Castilho et al. ${ }^{14}$ found that applying peppermint and cilantro essential oils inhibited sprouting of 'Agria' and 'Kennebec' cultivars, with inhibition rates between 65 and 95\% compared to control tubers. Likewise, Coleman et al. ${ }^{8}$ observed the efficacy of several compounds, including menthol, neomenthol and linalool, which suppressed sprouting in potato tubers from 'AC Novachip', 'Russet Burbank', 'Shepody' and 'Snowden' cultivars stored at $10{ }^{\circ} \mathrm{C}$. Abbasi et al. ${ }^{15}$ found that clove oil was more efficient in reducing sprouting than spearmint oil on cultivar Lady Rosetta. In our work however, menthol was more efficient than eugenol (Figure 2 and 3). This might be due to the purity and source of Mentha species utilized on the essential oil extraction.

The end of the tuber dormancy period is characterized by the beginning of sprouting, with strong apical dominance and inhibition of growth on the lateral buds. The removal of the apical bud or the attenuation of apical dominance stimulates sprouting of the lateral buds ${ }^{16}$, which explains the increase in the number of lateral buds observed on eugenol and menthol treated tubers (Figure 3). Because of the caustic effect of the essential oils treatments, the damage on the dominant apical bud, the essential oils stimulated the growth of axillary buds. 


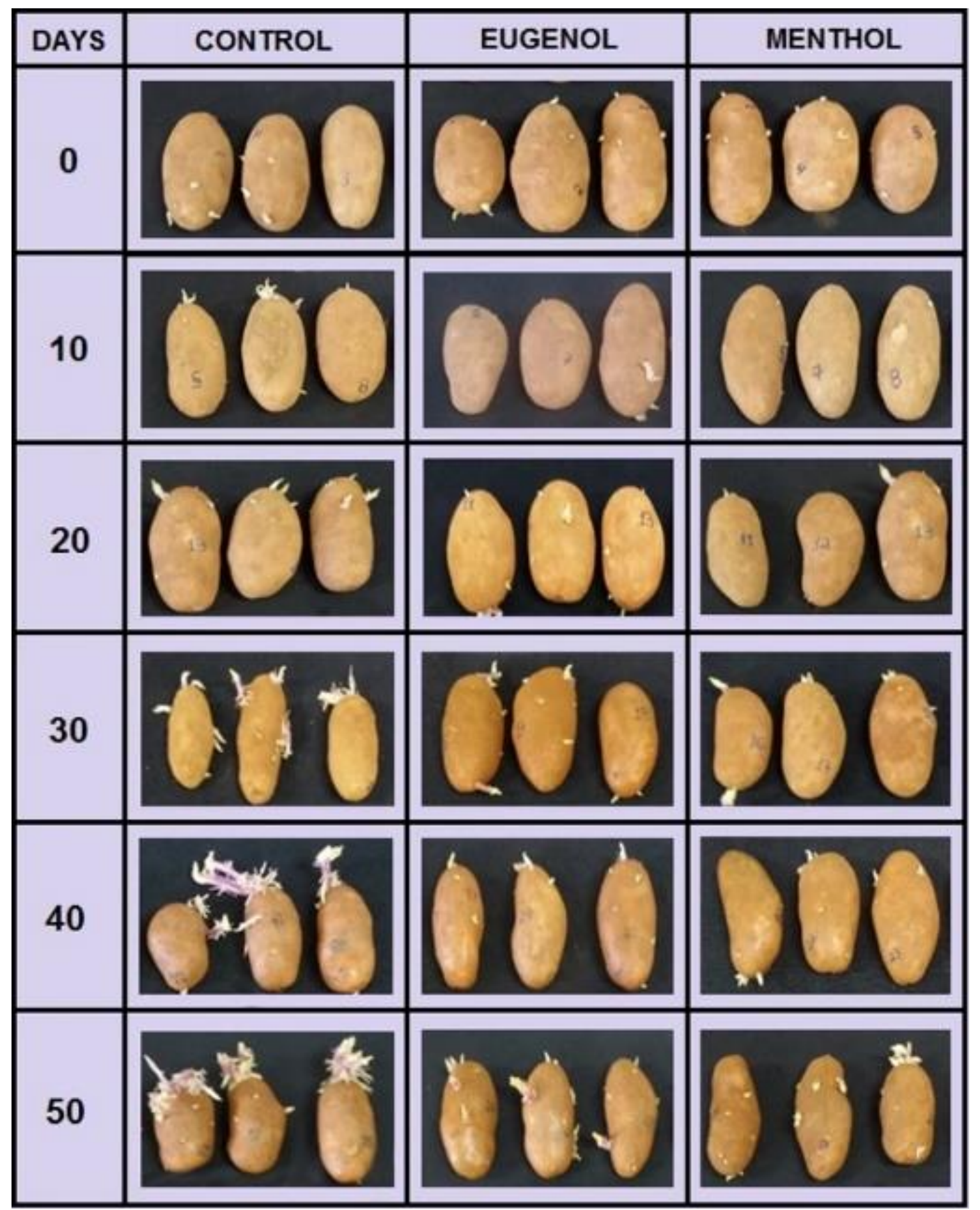

Figure 3. Appearance of 'Asterix' potato tubers treated with eugenol and menthol during the storage after 10, 20, 30,40 and 50 days at $8{ }^{\circ} \mathrm{C}$.

After 10 days from the treatment with eugenol and menthol, potatoes showed sprouts with a length inferior to control tubers in 0.95 and $1.23 \mathrm{~mm}$, respectively, and the untreated tubers, had sprouts with $2.05 \mathrm{~mm}$ in length. The effectiveness of the compounds can be noted up to the end of storage (50 days), where the sprouts length 
reached 4.74, 2.8 and $1.8 \mathrm{~mm}$ for the control, eugenol and menthol, respectively (Figure 4). Similar results were obtained using macerated cumin, which contains eugenol as a component providing reduction in the sprout size in potato seeds ${ }^{17}$. Owolabi et al. ${ }^{18}$ also found that essential oils from several sources reduced the length of 'Russet Burbank' sprouts compared to control tubers.

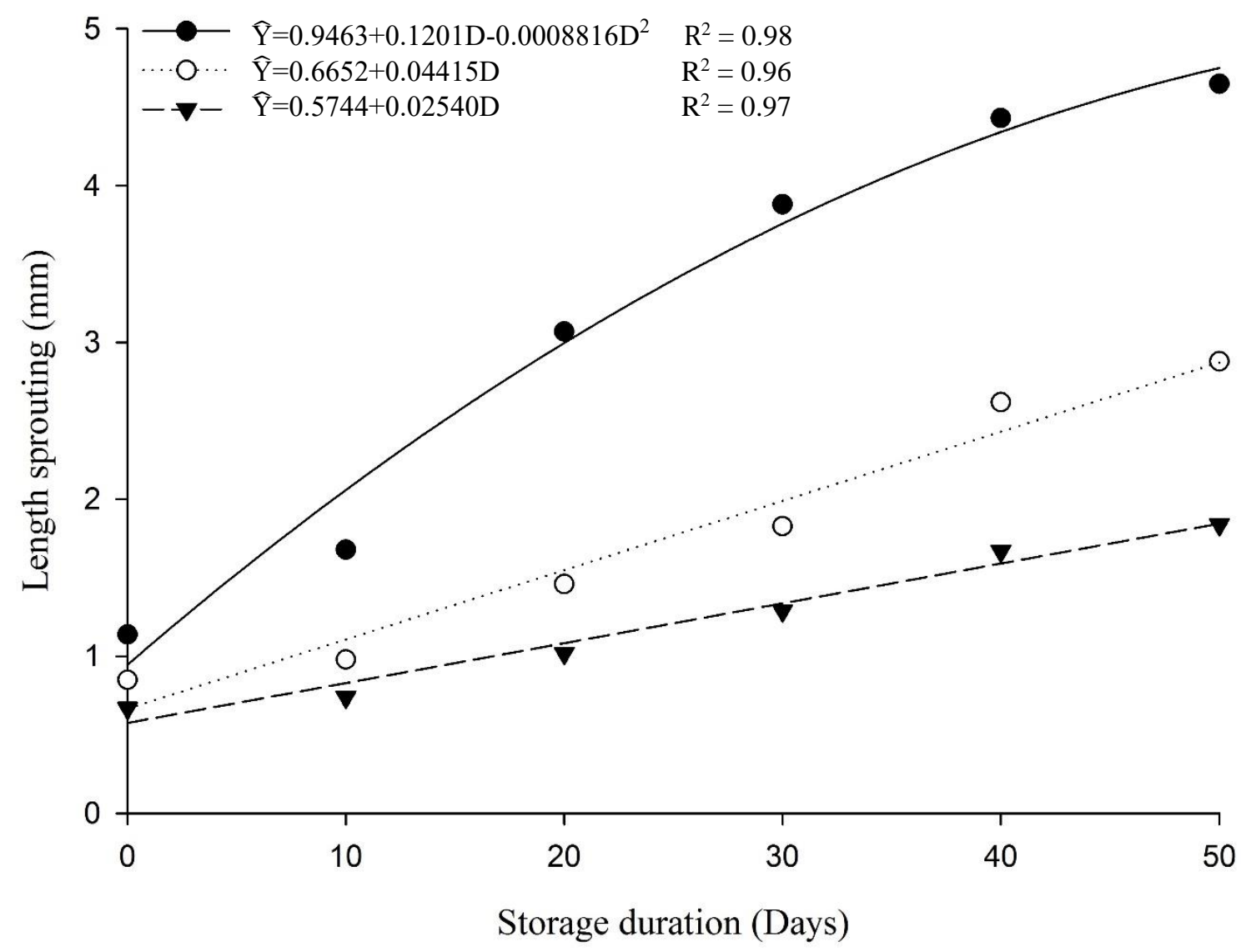

Figure 4. Sprout length $(\mathrm{mm})$ of 'Asterix' potato tubers through storage at $8^{\circ} \mathrm{C}$. Control $(\bullet)$, eugenol $(\circ)$ e menthol $(\boldsymbol{\nabla}$ treated tubers.

In addition to reducing the rate of sprouting in potato tubers, the compounds used showed some antifungal activity in the treated tubers, since the clove and menthol oils reduced the infection of Penicillium sp. (data not shown). Goméz-Castilho et al. ${ }^{14}$ reported that after the tubers were treated with essential oils of peppermint and coriander, they were free of any phytopathogenic damage for 'Agria' and 'Kennebec' tubers stored at $25^{\circ} \mathrm{C}$.

The essential oils inhibit the eyes sprouts by causing necrotic damage on the bud meristem (Figure 5). The anatomical analysis of buds revealed that tubers treated with eugenol and menthol had sprouting inhibited mainly by causing injury in the apical meristem, leading to sprout necrosis. Unlike the essential oils treated tubers, bud meristems from the control tubers remained intact without any lesion on the external layer of cells during storage (Figure 5B and 5C). Ten days after the essential oil treatments, tubers presented the apical meristem with wounded protoderm (Figure 5D and $5 \mathrm{~F})$. 
Leaf primordial in the more developed sprouts, signaled by arrows in the Figure 5, led to necrosis due to the damage caused eugenol (Figure 5D) and menthol (Figure 5F) in the procambium, which is responsible for the formation of the vascular bundles.

After 50 days from the treatments, the inhibitory effect of the compounds was decreased and axillary buds started to sprout. But, effects of eugenol (Figure 5E) and menthol (Figure 5G) treated tubers still showed remains of damaged superficial bud cells. Likewise, Teper-Bamnolker et al. ${ }^{19}$ evidenced through histological observations of the apical meristem in eight potato cultivars that the treatment with peppermint essential oil caused damage to vascular tissue in the first phase of the development, probably leading to total destruction of the sprout. The authors found that after four weeks, the inhibitory effect of the essential oil was decreased and axillary bud growth was noticed.
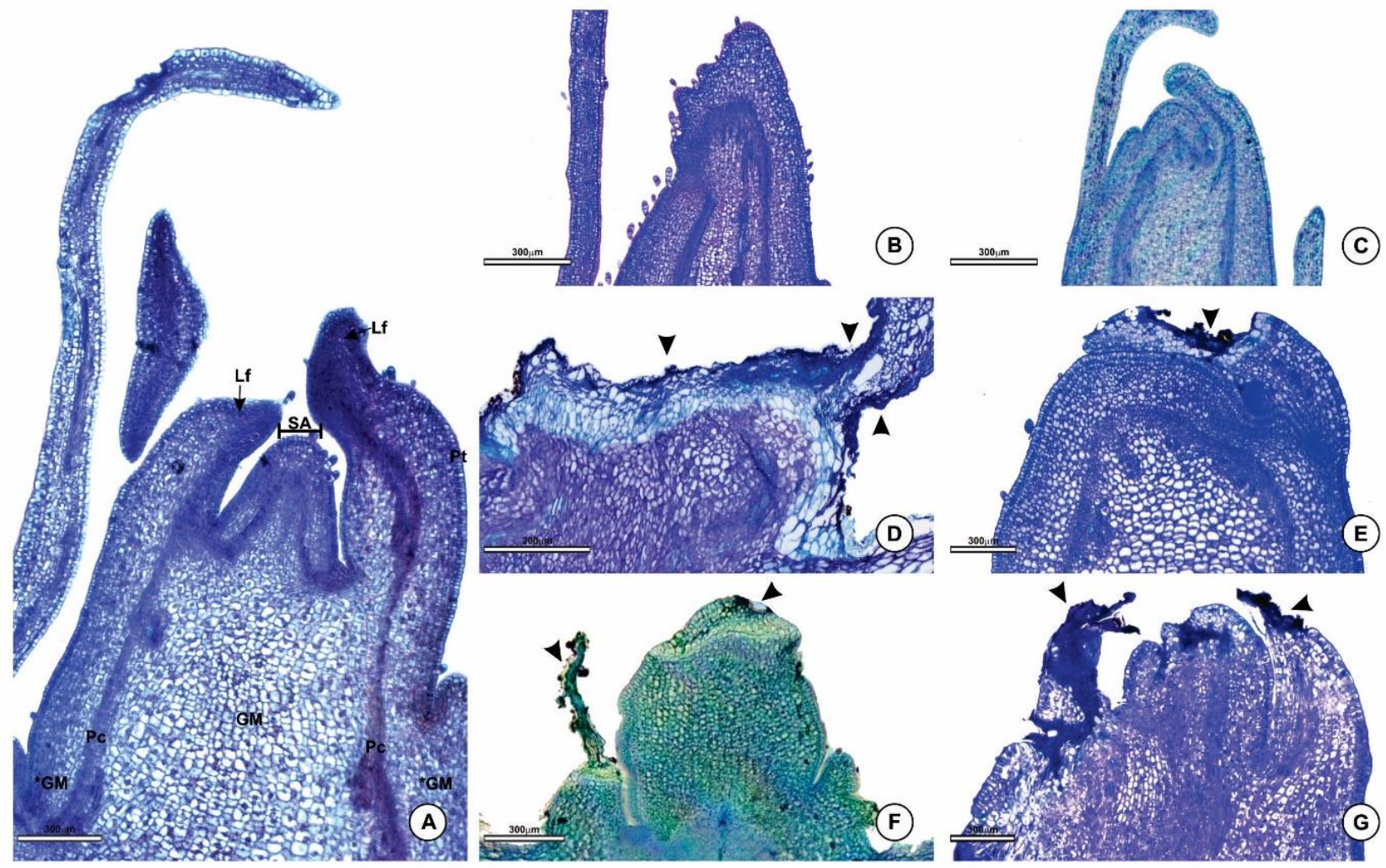

Figure 5. Longitudinal sections of sprouts of 'Asterix' potato tubers during storage, stained with toluidine blue (photomicrographs) under light microscopy. (A) time 0 of the experiment, (B) control with 10 days storage, (C) control with 50 days of storage, (D) 10 days after eugenol application, (E) 50 days after eugenol application, (F) 10 days after menthol application, (G) 50 days after menthol application. Arrow heads indicate necrotic regions in sprouts. Pf, leaf primordia; Pm, promeristem, Mf, fundamental meristem; Pc, procambium; Pt, protoderm. Bar $=300 \mu \mathrm{m}$.

The periderm of potato tuber, skin or peel, is formed by phellum, phellogen and phelloderm, functioning as barrier to protect the tuber against the action of pathogens, dehydration and physical damages ${ }^{20}$. The walls of the periderm cells are impregnated with suberin biopolymers, being essential for the periderm resistance and protect the cells from dehydration ${ }^{21}$. Regardless the treatment, the number and visual shape of the periderm cells were not affected by the essential oils or length of storage (Figure 6). Comparing the periderm structure at 10 and 50 days of storage is evident that the action of essential oils was virtually restricted only on the bud superficial meristematic cells (Figure 6A to 6G). 

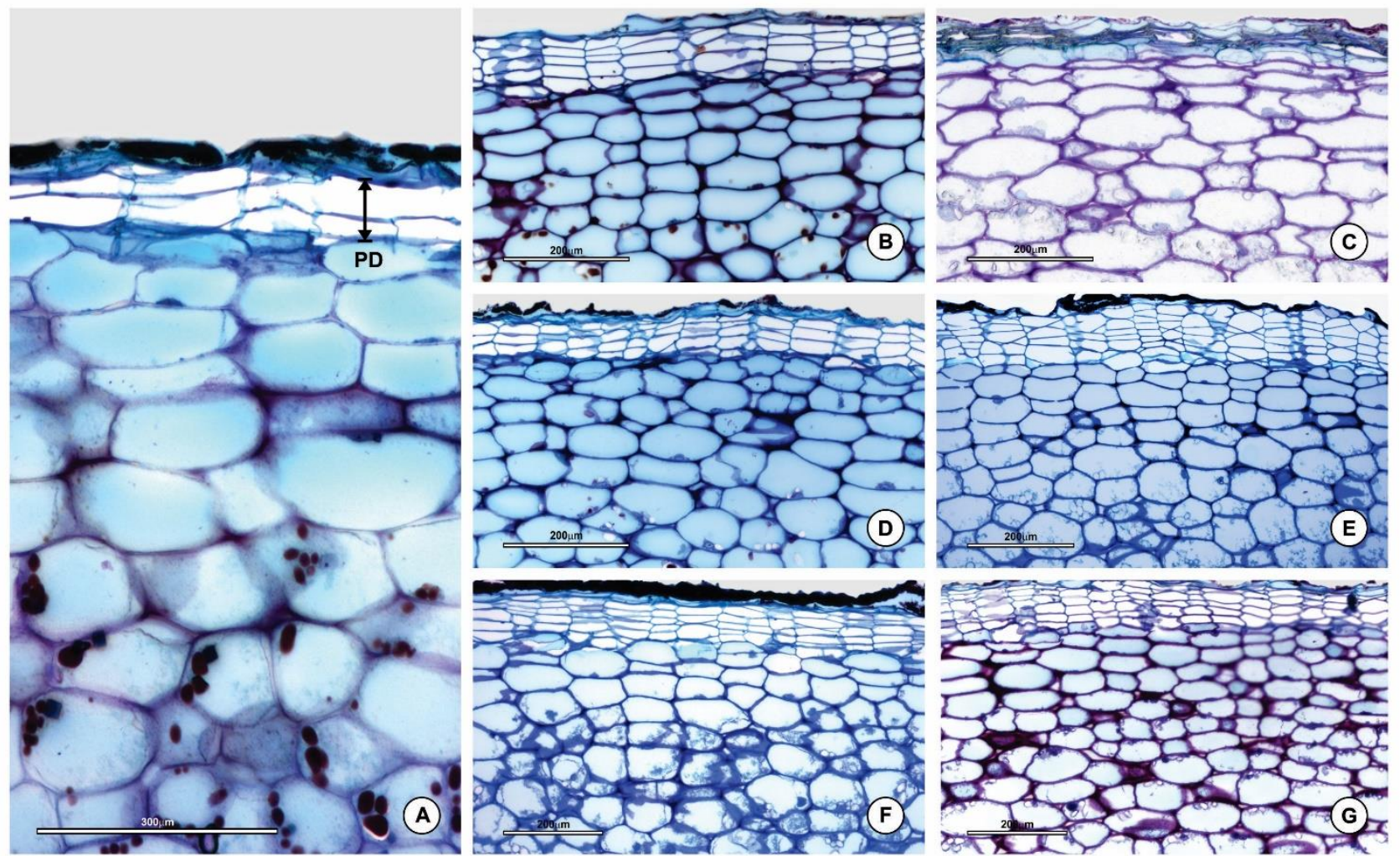

Figure 6. Cross (transverse) sections of the periderm of 'Asterix' potato tubers during storage, stained with toluidine blue (photomicrographs) under light microscopy. (A) at time of the experiment, (B) control with 10 days of storage, (C) control with 50 days of storage, (D) 10 days after eugenol application, (E) 50 days after eugenol application, (F) 10 days after menthol application, $(\mathrm{G}) 50$ days after menthol application. $\mathrm{PD}$, periderm. Bar $=200 \mu \mathrm{m}$.

\section{CONCLUSIONS}

Sprouting suppressive compounds, eugenol and menthol, reduce the number and the length of sprouted buds thorough refrigerated storage, inducing necrosis of the superficial meristematic cells. The effectiveness of the essential oils in repressing bud growth diminishes over time after the treatment. The oils break the apical dominance and induce axillary bud sprouting. Repeated applications of oils are necessary to prolong the effects on bud growth.

\section{Acknowledgements}

The authors thank CNPq, CAPES and FAPEMIG for their financial support.

\section{REFERENCES}

1. Instituto Brasileiro de Geografia e Estatística. - IBGE. Estatística da Produção Agrícola. Rio de Janeiro: IBGE, 2016.

2. Brasil Food Trends 2020 São Paulo, FIESP-ITAL, 2010.176 p.

3. BrasilHortifruti- Edition $\mathrm{n}^{\circ} 130$ www.hfbrasil.org.br/br/revista/acessar/estatistica/anuario2013-2014.aspx

4. Angelis S. Bem Brasil cresce e aparece nas principais capitais do país. Disponível em: http://www.bembrasil.ind.br/imprensa/bem-brasil-cresce-e-aparece-nas-principais-capitais-dopais/. (Accessed 03/01/2018).

5. Suttle JC, Campbell MA, Olsen NL. Potato tuber dormancy and postharvest sprout control. In: Pareek S (Ed.), Postharvest ripening physiology of crops. 1st $^{\text {st }}$. Boca Raton:CRC Press; 2016 p. $449-476$. 
6. Kleinkopf G, Oberg N, Olsen N. Sprout inhibition in storage: current status, new chemistries and natural compounds. Am J Potato Res. 2003; 80:317-327.

7. Hartmans KJ, Diepenhorst P, Bakker W, Gorris LGM (1995) The use of carvone in agriculture: sprout suppression of potatoes and antifungal activity against potato tuber and other plant diseases. Industrial Cropsand Products. 1995; 4:3-13.

8. Coleman WK, Lonergan G, Silk P. Potato sprout growth suppression by menthone and neomenthol, volatile oil components of minthostachys, satureja, bystropogon, and mentha species. Am J Potato Res. 2001; 78:345-354.

9. Elbashir HA, Ahmed AHR, Yousif KS. Efficacy of different applications of spearmint oil on storability and processing quality of two potato varieties. J Agri-Food Applied Sci. 2014; 2:124133.

10. Frazier MJ, Olsen N, Kleinkopf G. Organic and alternative methods for potato sprout control is storage. University of Idaho Extension. 2004. Acessed 03/01/2018. http://www.cals.uidaho.edu/edcomm/pdf/CIS/CIS1120.

11. Vaughn SF, Spencer GF. Volatile monoterpenes inhibit potato tuber sprouting. Am Potato J.1991; 68:821-831.

12. Johansen DA. Plant Microtechnique. New York: McGraw-Hill; 1940.

13. Sistema para Análises Estatísticas - SAEG (2007) Versão 9.1: Viçosa: Fundação Arthur Bernardes. UFV.

14. Goméz-Castilho D, Cruz E, Iguaz A, Arroqui C, Vírseda P. Effects of essential oils on sprout suppression and quality of potato cultivars. Postharvest Biol Technol. 2013; 82:15-21.

15. Abbasi KS, Masud T, Ali S, Khan SU, Mahmood T, Qayyum A. Sugar-Starch metabolism and antioxidant potential in potato tubers in response to different antisprouting agents during storage. Potato Res. 2015; 58:361-375.

16. Eshel D, Teper-Bamnolker P. Can loss of apical dominance in potato tuber serves as a marker of physiological age? Plant Signaling \& Behavior. 2012; 7:1158-1162.

17. Sanli A, Karadogan T, Tonguç M, Baydar H. Effects of caraway (Carum carvi L.) seed on sprounting of potato (Solanum tuberosum L.) tubers under different temperature conditions. Turkish J Field Crops. 2010; 15:54-58.

18. Owolabi MS, Olowu RA, Lajide L, Oladimeji MO, Padilha-Camberos E, Fernández JMF. Inhibition of potato tuber sprouting during storage by the controlled release of essential oil using a wick application method. Ind Crops Products. 2013; 45, 83-87.

19. Teper-Bamnolker P, Dudai N, Fischer R, Belausov E, Shoseyov HO, Eshel D. Mint essential oil can induce or inhibit potato sprouting by differential alteration of apical meristem. Planta. 2010; 232:179-186.

20. Evert RF. Esau's plant anatomy, meristems, cells, and tissues of the plant body: their structure, function, and development. $3^{\text {rd }}$ ed. Madison: John Wiley \& Sons, Inc; 2006.

21. Lulai EC, Suttle JC, Pederson SM. Regulatory involvement of abscisis acid in potato tuber wound-healing. J Exp Bot. 2008; 59:1175-1186. 